\title{
The Use of Learning Logs Strategy in Improving Students' Ability in Writing Expository Paragraph
}

\author{
Agung Prasetyo Wibowo ${ }^{1]}$, Vonnysa Febrinda ${ }^{2]}$ \\ Universitas Muhammadiyah Riau \\ E-mail: ${ }^{1]}$ agungprasetyo.w@umri.ac.id \\ ${ }^{2]}$ vonnysafebrinda2000@gmail.com
}

\begin{abstract}
To see the difference in students' ability in writing expository paragraphs, this research uses a comparison between log learning and conventional learning strategies. Using trueexperimental research, there were pre-test, treatment, and post-test. The subject of this research was the first-year students of State Senior High School 1 Selatpanjang, Meranti Island Regency. Two classes were deployed; an experimental and a control class with total of 47 students. The researchers used cluster random sampling, based on the group. In collecting data, the researchers used a test and an observation list. In assessing students' writing, the researchers invited two raters, those who are qualified and considered as experts in teaching writing. The researchers analyzed the data by using t-test formula. The result shows that the mean score of students' post-test in the control class was 65,5. Meanwhile, the mean score of students' post-test in experimental class was 73,4. The result of $\mathrm{t}$ test sees a significant difference between students' ability in writing expository paragraphs by using Learning Logs Strategy and those using Conventional Strategy (5.26). This result was higher than $t$ table significant $5 \%(2,02)$ and $1 \%(2,69)$. Ho was rejected and Ha was accepted. It means that there was a significant difference in students' ability in writing an expository paragraph using Conventional Strategy and using Learning Logs Strategy.
\end{abstract}

Keyword: Writing, Expository Paragraph, Learning Log Strategy, Experimental Research

\section{Penggunaan Strategi Learning Logs dalam Meningkatkan Kemampuan Siswa dalam Menulis Paragraf Eksposisi}

\begin{abstract}
Abstrak
Untuk melihat perbedaan kemampuan siswa dalam menulis paragraf eksposisi, penelitian ini menggunakan perbandingan antara strategi pembelajaran Learning Log dan strategi pembelajaran konvensional. Penelitian ini menggunakan penelitian true-experiement. Subjek penelitian ini adalah siswa/i kelas XI SMAN 1 Selatpanjang, Kabupaten Meranti. Dua kelas dilibatkan; kelas eksperimen dan kontrol dengan total 47 siswa. Para peneliti menggunakan pengelompokan sampel acak berdasarkan kelompok. Dalam mengumpulkan data, peneliti menggunakan tes dan daftar observasi. Dalam penelitian ini, peneliti menganalisis data secara manual dengan menggunakan rumus $t$-test. Hasil penelitian menunjukkan bahwa skor rata-rata post-tes siswa di kelas kontrol adalah 65,5. Sementara itu, skor rata-rata post-tes siswa di kelas eksperimen adalah 73,4. Hasil uji t terlihat adanya perbedaan yang signifikan antara siswa/i yang menulis paragraf eksposisi dengan mereka yang menggunakan Strategi Learning Log dan yang menggunakan Strategi Konvensional (5.26). Hasil ini lebih tinggi dari t tabel signifikan 5\% (2,02) dan 1\% (2,69). $\mathrm{HO}$ ditolak dan $\mathrm{Ha}$ diterima. Ini berarti bahwa ada perbedaan yang signifikan dalam kemampuan siswa dalam menulis paragraf eksposisi dalam menggunakan Strategi Konvensional dan menggunakan Strategi Learning Log.
\end{abstract}

Kata kunci: Writing, Paragraf Eksposisi, Learning Log Strategy, Penelitian Eksperimental 


\section{INTRODUCTION}

Writing is a transcription of composing ideas: it is not the product of thought, but it is an actualization and dramatization of words (Kurtz, 2017). This means that writing is the way to explore ideas as it needs to be composed within a medium such as a paper and how to deliver ideas to the readers. Martin (2015) states that writing sounds simple start with attention - grabbing the first sentence and then move onto some really interesting stuff in the middle and then bring it all together up to the end. This can be understood that an interesting feeling to write should be encouraged as it will make the writer feels easy to write.

However, in regards to the pedagogical aspect, there seems to be the priority than others. According to Zaim and Ningsih (2019) that the action to improve the writing curriculum often focuses on the pedagogical techniques to make didactic and sequences more effective and another focus is to raise the students' interest in writing, assuming that increased interests lead to more involvement in learning. So, as stated above that interesting feeling becomes one of the factors to support writing ability.

Besides, a shared body of knowledge and experience is essential to the writer's successful communication, and to the readers' understanding of a message. In delivering the messages, the students have to comprehend the kind of paragraph that state about information or clarifying the process and this is included in the expository paragraph. Expository Paragraph is to give information, explain why or how, clarify a process, or define a concept (Morrow, 2018). In a paragraph, it can be as short as one sentence or as long as ten sentences, but the number of sentences is unimportant; however, the paragraph should be long enough to develop the main idea clearly (Adam and Van Manen, 2017). In writing an expository paragraph, the students at Senior High School particularly are confused to arrange and to connect information that the. Students have to be good sentences and then it becomes a good expository paragraph. Hence, to write an expository paragraph seems difficult for the students of Senior and Junior High School.

According to curriculum 2013, that writing is one of the compulsory skills that should be taught and learned by students in the school. They also study how to write many kinds of genres, and expository is one of the genres that the students have to master to write. According to the syllabus from the 10th grade at SMA N 1 Selatpanjang that one of the indicators mentioned that the students need to be able to write a descriptive paragraph, narrative paragraph, and expository paragraph. Based on the preliminary research at the school, the teacher used an Oldfashioned Strategy in teaching writing and explaining the material about the paragraph. Ideally, the students were able to comprehend the paragraphs, but the reality said conversely. The teacher still found some problems happening in writing several paragraphs, especially in the expository paragraph. So that it can be itemized into the following phenomena:

1. Some of the students cannot arrange the information to be a good expository paragraph 
2. Some of the students cannot choose appropriate topics in writing an expository paragraph

3. Some of the students cannot select appropriate vocabulary in writing an expository paragraph

4. Some of the students do not know how to select a topic sentence and supporting the idea in writing an expository paragraph

Assumption and Hypothesis

The researchers assume that (1) students' ability in writing an expository is various, and (2) Students' writing ability is influenced by many factors.

Hypothesis

Ho: There is no significant difference ability of students in writing expository paragraph by using Learning Logs Strategy at the first year of SMA N 1 Meranti Island Regency

Ha: There is significant difference ability of students in writing expository paragraph by using Learning Logs Strategy at the first year of SMA N 1 Meranti Island Regency

\section{Teaching Writing Strategy}

In teaching writing, the teacher can focus on the product of the writing or the process of writing itself. In concerning the product of writing, it seems that the writer is only interested in the aim of task and the end of the task. Meanwhile, if the focus on the process of writing, it means that the teacher will be together with the students in the process of pre-writing phase, editing, redrafting, and finally in publishing the students' product, it will be an approach process to get to the heart of the various skills that should be employed when writing. It is suggested to stress that writing is rewriting, that re-vision - seeing with new eyes - has a central role to play in the act of creating text (Hyland, 2015). In their model, process of writing is an interrelated set of recursive stages which includes:

- Drafting

- Structuring, ordering information,

experimenting with arrangements, and etc

- Reviewing (checking context, connections, assessing impact, editing)

- Focusing (that is making sure you are getting the message across you want to get across)

- Generating ideas and evaluation (assessing the draft and/or subsequences draft)

One of the advantages to get the students concentrate to the process of writing is that it takes time: time to brainstorm ideas or to collect them in some other ways, time to draft a piece of writing and then, with teachers help to see whether it has been a good result or not. Teaching writing strategy can be various and it will influence toward the ability of students in writing several kinds of paragraph, text, essay, and so forth. There are many kinds of strategy that can be used in teaching writing. Mostly teachers use conventional method. Based on phenomena happening in the field, conventional method is general method which is used by teacher by explaining the material, there is asking and answering session, afterwards the students are begged to do the task. This strategy usually makes students feel bored and cannot comprehend the material. Therefore, the researchers recommend one of strategies that is called Learning Logs Strategy. 


\section{Component of Paragraph}

It is important to highlight that a good paragraph should consist of general statement or topic sentence. Within a topic sentence, controlling idea is attached as it will limit the discussion of the paragraph (Harmer, 2012). Supporting ideas in further describe the detail information that support controlling idea in a topic sentence. After all the detail is well elaborated, thus a concluding sentence signals a closing. It leaves the readers with important points to remember since it's as general as the topic sentence.

There are many kinds of genres, studied at Senior High School. One of the genres is Expository. According to Herrington et al, (2009), Expository Paragraph is to give information, explain why or how, clarify a process, or define a concept. Giving information is to share something, needed by readers. Meanwhile to explain why or how indicates to a reason and the manner of something and to clarify a process and define a concept. The example of expository paragraph can be seen as follows:

\section{My Favorite}

I have two favorite flowers. These flowers are pansy and petunias. My first favorite flower is pansy. I like pansies because they give me color through the winter months when everything else is drab. My second favorite flower is petunia. In summer, petunias weather the hot, dry months well and keep me in color until the killing frost. With pansies and petunias, I have color all year long.

Expository Paragraph is needed by students because most of the reading sources are expository material such as, newspaper, magazine, and many others. In addition, the most common expository structures include description, enumerative or listing, sequence, comparison and contrast, cause and effect and problem and solution (Woodrad, 2016).

Several phenomena happened because the teachers used an inappropriate strategy in teaching English. Whereas in improving a writing skill particularly in writing expository paragraph, it is suggested to adopt a more appropriate strategy that this is expected to improve students' ability in writing. In this research, a new strategy in teaching writing that so-called Learning Logs Strategy is offered to be adjusted in teaching and learning in the classroom. Learning Logs Strategy is a strategy to help students focusing on what they are learning in their classes by writing their thought, reactions, and responses to class lectures, videos, or discussion and it is a written reflection of students' perception of what is being learned and how they are learning (Ahmed and Abouabdelkader, 2016). In this case, learning logs strategy is effective for the students in writing expository paragraph because it records the ideas of what they have already known. Writing learning logs is an excellent way to help the students to use writing as a process of discovery and to clarify ideas. Saskatoon Public School has implemented Learning Logs Strategy that Learning Logs strategy has the most valuable result that the students learn to write, they also learn to recognize their own and other's good work. So, Learning Logs Strategy is one of the effective ways to improve students' ability in writing. Therefore, the researchers are interested in conducting research entitled "The Use of Learning Logs Strategy in Improving Students' Ability in Writing Expository Paragraph“. 


\section{METHOD}

This is experimental research, used to establish to find any possibilities of cause and effect between independent and dependent variables (Creswell, 2017). The true-experimental research design was deployed and assigned participants to different condition of the experimental variable, individuals in the experimental group received the experimental treatment, whereas those in the control group did not (ibid, 2017). The samples of this study were 10th graders in Senior High School 1 Selatpanjang consisting of two classes; experiment class and control class. The classes were given one posttest at the end of the research. The result of the test was analyzed by using the statement to know whether there was a significant difference in the strategy of the writer used or not. This design involved a single group that was posttest and the success of this research was determined by a posttest. In collecting the data, the researcher used a writing test as the instruments. There are five components such as Content, Organization, Vocabulary, Language Use, and Mechanics in assessing the score of writing ability (Martin, 2015).

In analyzing the students' ability i $\mathrm{n}$ writing an expository paragraph, the researcher used the minim um standard score of English Subject in the school the researchers did the research. It is 65 for students' writing ability. It means that if the students cannot reach the standard, they cannot pass the score. The technique of data analysis used in this research is the t-test formula (Hartono, 2008, p.216) as follows.

$$
\begin{aligned}
& \text { to } \quad=\text { the value of } \mathrm{t} \text { - obtained } \\
& \mathrm{M}=\text { the mean score of experimental } \\
& \text { class } \\
& \text { My }=\text { the mean score of control class } \\
& \text { SDx }=\text { standard deviation of } \\
& \text { experimental class } \\
& \text { SDy }=\text { standard deviation of control } \\
& \text { class } \\
& \mathrm{N}=\text { the number of students } \\
& \text { The } \mathrm{t} \text { - table has the function to }
\end{aligned}
$$

see if there is a significant difference among the mean of score of both experimental and control group. The $\mathrm{t}-$ obtained value is consulted with the value of $\mathrm{t}-$ table at the degree of freedom $(\mathrm{df})=$ $(\mathrm{N} 1+\mathrm{N} 2)-2$ which is statically hypothesis:

Ha: to $>\mathrm{t}-$ table

Ho: to $<\mathrm{t}-$ table

$\mathrm{Ha}$ is accepted if to $>\mathrm{t}-$ table or there is a significant difference of using Learning Logs Strategy towards students' ability in writing an expository paragraph. Whilst, Ho is accepted if to $<\mathrm{t}-$ table or there is no significant difference of using Learning Logs Strategy towards students' ability in writing an Expository paragraph.

\section{Operational Concept}

Operational concept is the concept used to give an explanation about theoretical framework to avoid misunderstanding to words of the research. There are two variables which are used in this research. The first is Learning Logs strategy which refers to the teacher's strategy in teaching writing. The second is students' ability in writing an expository paragraph. So, Learning Logs Strategy is an independent variable and students' ability in writing expository

$$
=\frac{M x-M y}{\sqrt{\left(\frac{S D x}{\sqrt{N-1}}\right)^{2}-\left(\frac{S D y}{\sqrt{N-1}}\right)^{2}}}
$$


paragraph is a dependent variable. The indicators are the values and strategies applied in the implementation of various method or strategy. The indicators are:

The use of Learning Logs

Strategy as the independent variable, symbolized by " $\mathrm{X}$ "

- The teacher asks the students to use a special notebook or binder for learning logs entries.

- The teacher shares examples of learning $\log$ entries about what the teacher has written to serve as models for students.

- Give the students the prompts for short content-focused writing and allow them to practice writing entries.

- Do it regularly, daily and weekly. And then make it in one paragraph.

- Consider ways in which Learning Logs can be evaluated.

- Since log writing is typically short in length, written within a limited amount of time, and does not require much if any based on a weekly collection and check of the logs.

Students' ability in writing an expository paragraph, symbolized by "Y"

- The students are able to give information in English with the correct grammar in expository paragraph.

- The students are able to explain a subject in expository paragraph.

- The students are able to give directions in expository paragraph.

- The students are able to show how to do something in expository paragraph.

- The students know the component of paragraph, such as topic sentence, controlling idea, supporting idea, and concluding sentence in making expository paragraph.

\section{Reliability and Validity of the Test}

According to Zohrabi (2013), that reliability is associated with consistency of the scores produced and it is expressed numerically, usually as a reliability coefficient, which is obtained by using correlation. The high reliability coefficient indicates high reliability. So, the concept of reliability shows that the high result of reliability means that the test can be trustworthiness. In this case, the researchers used inter rater reliability to know the reliability of the writing test because the researchers took two raters to check the result of students' writing test. To know the correlation between two raters, the researchers adopt product moment formula as it describes if the correlated variable data have no any variances.

The formula is:

$\mathrm{r}_{\mathrm{xy}}=\frac{N \sum \boldsymbol{X} \boldsymbol{Y}-\left(\sum \mathbf{X}\right)\left(\sum \mathbf{Y}\right)}{\sqrt{\left[N \sum X^{2}-(\Sigma X)^{2}\right]\left[N \Sigma Y^{2}-\left(\Sigma Y^{2}\right]\right.}}$

For the coefficient of product moment correlation is compared through the degree of freedom (df) as follows:

$\mathrm{df}=\mathrm{N}-\mathrm{nr}$

$\mathrm{N}=$ Number of cases

$\mathrm{nr}=$ total variable correlated

Statistically, the hypotheses are:

$\mathrm{H}_{\mathrm{o}}=\mathrm{r}_{\mathrm{o}}<\mathrm{r}_{\mathrm{t}}$

$\mathrm{H}_{\mathrm{a}}=\mathrm{r}_{\mathrm{o}}>\mathrm{r}_{\mathrm{t}}$

$\mathrm{H}_{\mathrm{o}}$ is accepted if $\mathrm{r}_{\mathrm{o}}<\mathrm{r}_{t}$ or there is no significant correlation between score of rater 1 and score of rater 2 .

$\mathrm{H}_{\mathrm{a}}$ is accepted if $\mathrm{r}_{\mathrm{o}}>\mathrm{r}_{\mathrm{t}}$ or there is significant correlation between score of rater 1 and score of rater 2 .

The following is the table that describes the scores of post-test in experimental class between score of rater 1 and rater 2. 
Table 1 Post-test score of experimental class between rater 1 and rater

\begin{tabular}{cccccc}
\multicolumn{7}{c}{2} & \multicolumn{5}{c}{$\mathbf{X}^{\mathbf{2}}$} & $\mathbf{Y}^{\mathbf{2}}$ \\
\hline $\mathbf{N o}$ & $\mathbf{X}$ & $\mathbf{Y}$ & $\mathbf{X Y}$ & 8281 & 9409 \\
\hline 1 & 91 & 97 & 8827 & 4225 & 4761 \\
2 & 65 & 69 & 4485 & 4761 & 5929 \\
3 & 69 & 77 & 5313 & 5184 & 6400 \\
4 & 72 & 80 & 5760 & 5625 & 6889 \\
5 & 75 & 83 & 6225 & 2304 & 3249 \\
6 & 48 & 57 & 2736 & 4225 & 5184 \\
7 & 65 & 72 & 4680 & 3969 & 5329 \\
8 & 63 & 73 & 4599 & 5624 & 5929 \\
9 & 68 & 77 & 5236 & 5776 & 7225 \\
10 & 76 & 85 & 6460 & 3600 & 4489 \\
11 & 60 & 67 & 4020 & 4356 & 4900 \\
12 & 66 & 70 & 4620 & 3364 & 3969 \\
13 & 58 & 63 & 3654 & 6084 & 4489 \\
14 & 78 & 67 & 5226 & 5489 & 6084 \\
15 & 67 & 78 & 5226 & 2601 & 4489 \\
16 & 51 & 67 & 3417 & 2500 & 4489 \\
17 & 50 & 67 & 3350 & 259 \\
18 & 67 & 77 & 5159 & 4489 & 5929 \\
19 & 55 & 65 & 3575 & 3025 & 4225 \\
20 & 70 & 85 & 5950 & 4900 & 7225 \\
21 & 72 & 80 & 5760 & 5184 & 6400 \\
22 & 78 & 85 & 6630 & 6084 & 7225 \\
23 & 80 & 90 & 7200 & 6400 & 8100 \\
\hline $\mathbf{N =}$ & $\sum \mathbf{X =}$ & $\sum \mathbf{Y = 1 7}$ & $\sum \mathbf{X Y = 1 1}$ & $\sum \mathbf{X}^{\mathbf{2}=106}$ & $\sum \mathbf{Y}^{\mathbf{2}} \mathbf{1}$ \\
$\mathbf{2 3}$ & $\mathbf{1 5 4 4}$ & $\mathbf{3 1}$ & $\mathbf{8 1 0 8}$ & $\mathbf{0 5 0}$ & $\mathbf{3 2 3 1 7}$ \\
\hline & & & & &
\end{tabular}

The formula is:

$$
\begin{aligned}
& \mathbf{r}_{\mathrm{xy}}=\frac{N \sum \boldsymbol{X Y}-\left(\sum \mathbf{X}\right)\left(\sum \mathbf{Y}\right)}{\sqrt{\left[N \sum X^{2}-\left(\sum X\right)^{2}\right]\left[N \sum Y^{2}-\left(\sum Y^{2}\right]\right.}} \\
& \mathbf{r}_{\mathrm{xy}}= \\
&
\end{aligned}
$$

$\sqrt{\left[23.106 .050-(1544)^{2}-\left[23.132 .3172-(1731)^{2}\right]\right.}$

$r_{x y}=\frac{(2.716 .484)-2.672 .664}{\sqrt{[55,214-46,930}}$

$\mathrm{r}_{\mathrm{xy}}=\frac{43.820}{\sqrt{2.591 .193 .020}}$

$r_{x y}=\frac{43.820}{50.903,8}$

$r_{\mathrm{xy}}=0.861$

The result of the product moment $\left(r_{o}\right)$ formula which is compared between rater 1 and rater 2 is 0,861 . In comparing with $\left(r_{t}\right)$, the researcher has to obtain the degree of freedom (df) as follows:

$\mathrm{df}=\mathrm{N}-\mathrm{nr}$

$=23-2$

$$
=21
$$

After getting the result of degree of freedom, the co-efficient of correlation of product moment is compared with $\mathrm{r}$ table either at $5 \%$ and $1 \%$. After checking at $r$ table, 21 is not available. Therefore, the researcher takes df 24 as the nearest. At the level $5 \%, \mathrm{r}_{\mathrm{t}}$ is 0,388 and at the level $1 \%, r_{t}$ is 0,496 . Based on $r$ table, it can be analyzed that $r_{o}>r_{t}$ either at level $5 \%$ and $1 \%$. On the other word, $0,388<$ $0,861>0,496$ which can be concluded that there is a significant correlation between score of rater 1 and rater 2 and the test is reliable.

Validity means that the most important characteristics of a test and it is concerned with the appropriateness of the interpretations made from test scores (Zohrabi, 2013) In this case, the researchers took Validity content because Validity content constitutes a representative sample of the language skills, structure, and etc. (Ibid, 2013). It has purpose to examine whether the test is a good representation of the material that need to be tested. The test is a good reflection of what material that has been taught and of what knowledge which the researchers want the sample to know. The test had fulfilled the validity content because the material of the test had been taught at the first year student of State Senior High School 1 Selatpanjang, Meranti Regency.

\section{FINDINGS AND DISCUSSION}

The goal of this research is to know how the students' ability after being taught by using conventional strategy in writing an expository paragraph was, to know how the students' ability after being taught by using Learning Logs Strategy in writing an expository paragraph was, and to obtain whether there was a significant 
difference of students' ability in writing an expository paragraph between the students who were taught by using Learning Logs Strategy and those who were taught without Learning Logs Strategy. The data of this research was taken from test, post-test.

The data of the students' scores of post-test for both of the classes: an experimental and a control class. Pre-test was done for both of the samples in those two classes. The scores of pre-test showed that both of the classes had no significant different score. It means that, both of their writing ability was homogenous.

In the experimental class, the researchers had already taught the samples by using Learning Logs Strategy, meanwhile in the control class, the researchers had only taught by using conventional strategy. Post tests were given to both of the classes after doing the treatment. And the results were evaluated by two raters.

The difference of pre-test score between the control and experimental classes

To explain the data, the researcher compared the students' writing ability score for both of the classes (experimental and control classes) in the Table 2 below:

Table 2 Students' pre-test score of the experimental and control class

\begin{tabular}{|c|c|c|c|c|c|c|c|c|c|}
\hline \multirow{2}{*}{ No } & \multirow{2}{*}{ Student } & \multicolumn{4}{|c|}{$\begin{array}{c}\text { Control } \\
\text { Class }\end{array}$} & \multicolumn{4}{|c|}{ Experimental Class } \\
\hline & & Score & $\begin{array}{l}\text { Range } \\
\text { Score }\end{array}$ & Frequency & $\begin{array}{c}\text { Minimum } \\
\text { Standard } \\
\text { Score }\end{array}$ & Score & $\begin{array}{l}\text { Range } \\
\text { Score }\end{array}$ & Frequency & $\begin{array}{c}\text { Minimum } \\
\text { Standard } \\
\text { Score }\end{array}$ \\
\hline 1 & S1 & 50 & 43,5 & 1 & Not Pass & 91 & 44 & 3 & Not Pass \\
\hline 2 & S2 & 56,6 & 46 & 1 & Not Pass & 48,5 & 46,5 & 2 & Not Pass \\
\hline 3 & S3 & 48,5 & 46,5 & 7 & Not Pass & 55,5 & 47 & 1 & Not Pass \\
\hline 4 & S4 & 54 & 48 & 1 & Not Pass & 61 & 47,5 & 3 & Not Pass \\
\hline 5 & S5 & 46,5 & 48,5 & 1 & Not Pass & 47,5 & 48,5 & 1 & Not Pass \\
\hline 6 & S6 & 48 & 49 & 1 & Not Pass & 44 & 49,5 & 1 & Not Pass \\
\hline 7 & S7 & 54,5 & 50 & 1 & Not Pass & 46,5 & 51,5 & 1 & Not Pass \\
\hline 8 & S8 & 65 & 54 & 1 & Not Pass & 46,5 & 52,5 & 2 & Not Pass \\
\hline 9 & S9 & 46,5 & 54,5 & 3 & Not Pass & 56,5 & 53 & 1 & Not Pass \\
\hline 10 & S10 & 46,5 & 56,5 & 1 & Not Pass & 47,5 & 55,5 & 1 & Not Pass \\
\hline 11 & S11 & 46 & 57,5 & 1 & Not Pass & 47,5 & 56 & 1 & Not Pass \\
\hline 12 & S12 & 46,5 & 59,5 & 1 & Not Pass & 49,5 & 56,5 & 1 & Not Pass \\
\hline 13 & S13 & 46,5 & 61 & 1 & Not Pass & 44 & 59,5 & 1 & Not Pass \\
\hline 14 & S14 & 49 & 65 & 2 & Pass & 44 & 60 & 1 & Not Pass \\
\hline 15 & S15 & 46,5 & 70,5 & 1 & Pass & 52,5 & 60,5 & 1 & Not Pass \\
\hline 16 & S16 & 70,5 & & & & 52,5 & 61 & 1 & Not Pass \\
\hline 17 & S17 & 65 & & & & 47 & 91 & 1 & Pass \\
\hline 18 & S18 & 59,5 & & & & 59,5 & & & \\
\hline 19 & S19 & 61 & & & & 53 & & & \\
\hline 20 & S20 & 54,5 & & & & 56 & & & \\
\hline 21 & S21 & 46,5 & & & & 60,5 & & & \\
\hline 22 & S22 & 57,5 & & & & 51,5 & & & \\
\hline 23 & S23 & 43,5 & & & & 60 & & & \\
\hline 24 & S24 & 54,5 & & & & & & & \\
\hline \multicolumn{2}{|r|}{ Total } & 1263 & & 24 & & 1222 & & 23 & \\
\hline \multicolumn{2}{|r|}{ Mean } & 52,6 & & & & 53,1 & & & \\
\hline
\end{tabular}


The Table 2 shows the comparison between students' score in writing an expository paragraph in experimental and control class. The result of the score is conducted by the pre-test and the forms of the test for both of the class are same. The total score of control class is 1263 and the mean score is 52.6. Meanwhile the total score of experimental class is 1222 and the mean is 53.1. In this case, the students' writing expository paragraph ability in both class are relatively similar and both class are homogeneous.

In addition, the table also shows that the lowest score of the pre-test in control class is 43.5 and the highest score is 70.5. The modus of its score is 46.5, obtained by 7 students and there are only three students that can pass the standard minimum score. Meanwhile, the lowest score of the pre-test in the experimental class is 44 and the highest score is 91 . The modus of its score are 44 and 47.5 and there are three students that got those score. Even, only one person can pass the standard minimum score.

\section{The students' writing score in the post test}

Students' writing paragraph ability in control and experimental class can be seen through the explanation below. The data were analyzed to answer the formulation of the research and to prove the hypothesis of this research.
Table 3 Students' post test score in control class

\begin{tabular}{cccc}
\hline Student & $\begin{array}{c}\text { Rater } \\
\text { I }\end{array}$ & $\begin{array}{c}\text { Rater } \\
\text { II }\end{array}$ & $\begin{array}{c}\text { Final } \\
\text { Score }\end{array}$ \\
\hline S1 & 57 & 63 & 60 \\
S2 & 56 & 69 & 62,5 \\
S3 & 67 & 70 & 68,5 \\
S4 & 65 & 69 & 67 \\
S5 & 65 & 67 & 66 \\
S6 & 62 & 67 & 64,5 \\
S7 & 62 & 65 & 63,5 \\
S8 & 70 & 75 & 72,5 \\
S9 & 65 & 68 & 66,5 \\
S10 & 60 & 64 & 62 \\
S11 & 58 & 60 & 59 \\
S12 & 58 & 60 & 59 \\
S13 & 55 & 63 & 59 \\
S14 & 63 & 67 & 65 \\
S15 & 64 & 67 & 65,5 \\
S16 & 70 & 78 & 74 \\
S17 & 73 & 78 & 75,5 \\
S18 & 72 & 78 & 75 \\
S19 & 60 & 65 & 62,5 \\
S20 & 57 & 60 & 58,5 \\
S21 & 63 & 67 & 65 \\
S22 & 60 & 67 & 63,5 \\
S23 & 70 & 75 & 72,5 \\
S24 & 62 & 67 & 64,5 \\
\hline N = 24 & $\mathbf{1 5 1 4}$ & $\mathbf{1 6 2 9}$ & $\mathbf{1 5 7 1 , 5}$ \\
Mean & $\mathbf{6 3 , 1}$ & $\mathbf{6 7 , 9}$ & $\mathbf{6 5 , 5}$ \\
\hline & & & \\
\hline
\end{tabular}

Based on the data on the table above, the writer has found that the total score which is evaluated by rater 1 is 1514 , and the mean of score is 63.1. Meanwhile, the total score which is evaluated by rater II is 1629 , and the mean of the score is 67.9. At the same time, after summing up the score from rater I and rater II and then it is divided 2, the researcher finds the total score, it is 1571.5 and the mean is 65.5 . 
Table 4 Students' post test score in experimental research

\begin{tabular}{cccc}
\hline Student & Rater I & $\begin{array}{l}\text { Rater } \\
\text { II }\end{array}$ & $\begin{array}{c}\text { Final } \\
\text { Score }\end{array}$ \\
\hline S1 & 91 & 97 & 94 \\
S2 & 59 & 73 & 66 \\
S3 & 70 & 73 & 71,5 \\
S4 & 80 & 82 & 81 \\
S5 & 82 & 85 & 83,5 \\
S6 & 58 & 60 & 59 \\
S7 & 68 & 70 & 69 \\
S8 & 74 & 78 & 76 \\
S9 & 74 & 78 & 76 \\
S10 & 79 & 85 & 82 \\
S11 & 57 & 60 & 58,5 \\
S12 & 65 & 68 & 66,5 \\
S13 & 59 & 63 & 61 \\
S14 & 69 & 67 & 68 \\
S15 & 78 & 80 & 79 \\
S16 & 65 & 67 & 66 \\
S17 & 65 & 67 & 66 \\
S18 & 79 & 82 & 80.5 \\
S19 & 70 & 75 & 72.5 \\
S20 & 70 & 75 & 72.5 \\
S21 & 78 & 80 & 79 \\
S22 & 79 & 84 & 81.5 \\
S23 & 77 & 80 & 78.5 \\
\hline N=23 & $\mathbf{1 6 4 6}$ & $\mathbf{1 7 2 9}$ & $\mathbf{1 6 8 7 . 5}$ \\
Mean & $\mathbf{7 1 . 6}$ & $\mathbf{7 5 . 1}$ & $\mathbf{7 3 . 4}$ \\
\hline
\end{tabular}

Based on the data above, the researcher finds that the total score, evaluated by rater 1 is 1646 and the mean is 71.6. Meanwhile, the total score which is evaluated by rater II is 1729 and the mean is 75.1. After summing up both of the score and then it is divided 2, the researcher finds the total score obtained in the experimental score on the post test is 1687.5 and the mean is 73.4 .
Table 5 The calculation table of students' post test score in control class

\begin{tabular}{|c|c|c|c|c|}
\hline Score $(y)$ & $\begin{array}{c}\text { Frequ } \\
\text { ency } \\
(f)\end{array}$ & $F y$ & $f y^{2}$ & $\begin{array}{c}\text { Minimum } \\
\text { Standard } \\
\text { Score }\end{array}$ \\
\hline \multirow[t]{2}{*}{58,5} & 1 & 58, & 342 & Not Pass \\
\hline & & 5 & 2,25 & \\
\hline \multirow[t]{2}{*}{59} & 3 & 17 & 104 & Not Pass \\
\hline & & 7 & 43 & \\
\hline 60 & 1 & 60 & $\begin{array}{c}360 \\
0\end{array}$ & Not Pass \\
\hline 62 & 1 & 62 & $\begin{array}{c}384 \\
4\end{array}$ & Not Pass \\
\hline 62,5 & 2 & $\begin{array}{c}12 \\
5\end{array}$ & $\begin{array}{l}781 \\
2,5\end{array}$ & Not Pass \\
\hline 63,5 & 2 & $\begin{array}{c}12 \\
7\end{array}$ & $\begin{array}{l}806 \\
4,5\end{array}$ & Not Pass \\
\hline 64,5 & 2 & $\begin{array}{c}12 \\
9\end{array}$ & $\begin{array}{c}832 \\
0,5\end{array}$ & Not Pass \\
\hline 65 & 2 & $\begin{array}{c}13 \\
0\end{array}$ & $\begin{array}{c}845 \\
0\end{array}$ & Pass \\
\hline 65,5 & 1 & $\begin{array}{c}65 \\
5\end{array}$ & $\begin{array}{l}429 \\
0,25\end{array}$ & Pass \\
\hline 66 & 1 & 66 & $\begin{array}{c}435 \\
6\end{array}$ & Pass \\
\hline 66,5 & 1 & $\begin{array}{c}66, \\
5\end{array}$ & $\begin{array}{l}442 \\
2,25\end{array}$ & Pass \\
\hline 67 & 1 & 67 & $\begin{array}{c}448 \\
9\end{array}$ & Pass \\
\hline 68,5 & 1 & $\begin{array}{c}68 \\
5\end{array}$ & $\begin{array}{l}469 \\
2,25\end{array}$ & Pass \\
\hline 72,5 & 2 & $\begin{array}{c}14 \\
5\end{array}$ & $\begin{array}{l}105 \\
12,5\end{array}$ & Pass \\
\hline 74 & 1 & 74 & $\begin{array}{c}547 \\
6\end{array}$ & Pass \\
\hline 75 & 1 & 75 & $\begin{array}{c}562 \\
5\end{array}$ & Pass \\
\hline 75,5 & 1 & $\begin{array}{c}75 \\
5\end{array}$ & $\begin{array}{r}570 \\
0,25\end{array}$ & Pass \\
\hline Total & 24 & $\begin{array}{c}\sum f \\
y \\
= \\
15 \\
71, \\
5\end{array}$ & $\begin{array}{c}\sum f y^{2} \\
= \\
103 \\
520, \\
25\end{array}$ & \\
\hline
\end{tabular}

Based on the data in the table above, it can be found mean score and standard deviation of control class as follow. 


$$
\begin{aligned}
& M y=\frac{\sum f y}{N} \\
= & \frac{\mathbf{1 5 7 1 . 5}}{24} \\
= & \mathbf{6 5 . 5} \\
S D y= & \sqrt{\frac{\sum f y^{2}}{N}-\left\{\frac{\sum f y^{2}}{N}\right\}} \\
= & \sqrt{\frac{103520.25}{24}-\left\{\frac{1571.5^{2}}{24}\right\}} \\
= & \sqrt{4313.3-\left\{65.5^{2}\right\}} \\
= & \sqrt{4313.3-4290.25}
\end{aligned}
$$

$$
\begin{aligned}
& =\sqrt{23.05} \\
S D y & =4.8
\end{aligned}
$$

The table and data analysis show that the researcher has found the maximum score which is got by control class on the post test is 75.5 for one student and the lowest score is 58.5 for one student. In conclusion, there were only twelve students that passed the minimum standard score (65), and twelve students that did not pass. In addition, the mean score is 65.5 and Standard Deviation is 4.8.

Table 6 Calculation table of students' post test score in experimental class

\begin{tabular}{ccccc}
\hline $\begin{array}{c}\text { Score } \\
(\mathbf{x})\end{array}$ & $\begin{array}{c}\text { Frequency } \\
(\boldsymbol{f})\end{array}$ & $\boldsymbol{F x}$ & $\boldsymbol{f x}^{2}$ & $\begin{array}{c}\text { Minimum Standard } \\
\text { Score }\end{array}$ \\
\hline 58,5 & 1 & 58,5 & 3422,25 & Not Pass \\
59 & 1 & 59 & 3481 & Not Pass \\
61 & 1 & 61 & 3721 & Not Pass \\
66 & 3 & 198 & 13068 & Pass \\
66,5 & 1 & 66,5 & 4422,25 & Pass \\
68 & 1 & 68 & 4624 & Pass \\
69 & 1 & 69 & 4761 & Pass \\
71,5 & 1 & 71,5 & 5112,25 & Pass \\
72,5 & 2 & 145 & 10512,5 & Pass \\
76 & 2 & 152 & 11552 & Pass \\
78,5 & 1 & 78,5 & 6162,25 & Pass \\
79 & 2 & 158 & 12482 & Pass \\
80,5 & 1 & 80,5 & 6480,25 & Pass \\
81 & 1 & 81 & 6561 & Pass \\
81,5 & 1 & 81,5 & 6642,25 & Pass \\
82 & 1 & 82 & 6724 & Pass \\
83,5 & 1 & 83,5 & 6972,25 & Pass \\
94 & 1 & 94 & 8836 & Pass \\
\hline Total & $\mathbf{N}=\mathbf{2 3}$ & $\sum \boldsymbol{f x}=\mathbf{1 6 8 7 . 5}$ & $\sum \boldsymbol{\mathbf { 1 2 5 5 3 6 , 2 5 }}$ & \\
& & & & \\
\hline
\end{tabular}


Based on the data in the table above, it can be found mean score and standard deviation of experimental class as follow.

$$
\begin{gathered}
M x=\frac{\sum f x}{N} \\
=\frac{1687.5}{23} \\
=73.4 \\
S D x=\sqrt{\frac{\sum f y^{2}}{N}-\left\{\frac{\sum f y^{2}}{N}\right\}} \\
=\sqrt{\frac{125536.25}{23}-\left\{\frac{1687.5^{2}}{23}\right\}} \\
=\sqrt{5458-\left\{73.4^{2}\right\}} \\
=\sqrt{5458-5387.6} \\
=\sqrt{70.4} \\
S D x=8.4
\end{gathered}
$$

The table and data analysis show that the researcher has found the maximum score which is obtained by control class on the post test is 94 for one student and the lowest score is 58.5 for one student. In conclusion, there were twenty students that pass the minimum standard score (65), and three students that did not pass. In addition, the mean score is 73.4 and Standard Deviation is 8.4 .

The difference ability of students in writing an expository paragraph which were taught by using Learning Logs Strategy and which were taught without Learning Logs Strategy

Based on the data calculation above, the mean of the score obtained by the experimental class was 73.4 and standard deviation was 8.4. Meanwhile the mean of the score in the control class was 65.5, and Standard Deviation was 4.8. Finally, mean and Standard Deviation for both of the scores above was analyzed by using t-test formula as follows:

$$
\begin{aligned}
& t^{\circ}=\frac{M x-M y}{\sqrt{\left(\frac{S D x}{\sqrt{N-1}}\right)^{2}-\left(\frac{S D y}{\sqrt{N-1}}\right)^{2}}} \\
& =\frac{73.4-65.5}{\sqrt{\left(\frac{8.4}{\sqrt{23-1}}\right)^{2}-\left(\frac{4.8}{\sqrt{24-1}}\right)^{2}}} \\
& =\frac{73.4-65.5}{\sqrt{\left(\frac{8.4}{4.7}\right)^{2}-\left(\frac{4.8}{4.8}\right)^{2}}} \\
& =\frac{7.9}{\sqrt{(1.8)^{2}-(1)^{2}}} \\
& =\frac{7.9}{\sqrt{3.24-1}} \\
& =\frac{7.9}{\sqrt{3.24-1}} \\
& =\frac{7.9}{\sqrt{2.24}} \\
& =\frac{7.9}{1.5} \\
& =5.26
\end{aligned}
$$

The final of this research was testing hypothesis. From the calculation of the data above, it can be seen that to was 5.26 . The to was compared by getting degree of freedom (df).

Degree of freedom:

$$
\begin{aligned}
\text { df } & =(\mathrm{N} 1+\mathrm{N} 2)-2 \\
& =(23+24)-2 \\
& =(47)-2 \\
& =45
\end{aligned}
$$

The degree of freedom is 45 . After looking at t-table, the degree of freedom 45 in significant $5 \%$ and $1 \%$ are 2.02 and 
2.69. By comparing the degree of freedom above, it can be concluded that $2.02<5.26>2.69$. It means that $\mathrm{t}$ observed is higher than $\mathrm{t}$ table in significant $5 \%$ and $1 \%$. So, there is a significant difference of students' ability in writing an expository paragraph, taught by Learning Logs Strategy.

\section{CONCLUSION}

Based on the data analysis, the conclusion of this research can be seen as follows:

1. The students' ability in writing expository paragraph which was taught by using conventional strategy was lower than the students' ability in writing an expository paragraph by using Learning Logs Strategy. It was proven from the mean score and the total number of students who passed the minimum standard score. The mean score was 65.5 and the students who passed the minimum standard score was only twelve students from 24 students in control class.

2. The students' ability in writing expository paragraph which was taught by using Learning Logs Strategy was higher than the students' ability in writing an expository paragraph which was taught by using conventional strategy. It was proven from the mean score and the total number of students who passed the minimum standard score. The mean score was 73.4 and the students who passed the minimum standard score was twenty students from 23 students.

3. The hypothesis Ho was rejected and Ha was accepted. It means that there is a significant difference ability of students in writing an expository paragraph which was taught by using Learning Logs Strategy. It can be seen through the result of the data calculation. The to was 5.26, the researcher found that $2.02<5.26>$ 2.69. It indicated that to was higher than $\mathrm{t}$ table in significant $5 \%$ and $1 \%$.

Dealing with the conclusion of this research, the researcher would like to give some suggestions. The teacher can use Learning Logs Strategy as one of the strategies in teaching English Writing because it gives significant difference of the students' writing ability in expository paragraph. Therefore, teacher should know how to teach writing by using Learning Logs Strategy. Besides, teacher also should use many ways to encourage students in writing paragraph ability such as teachers make writing become fun and not a boring thing, teachers should use the media that can support Learning Process in the classroom such as in focus screen and teachers should be creative and have many resources in teaching writing.

\section{BIBLIOGRAPHY}

Adams, C., \& Van Manen, M. A. (2017). Teaching phenomenological research and writing. Qualitative Health Research, 27(6), 780-791.

Ahmed, A., \& Abouabdelkader, H. (Eds.). (2016). Teaching EFL Writing in the 21st Century Arab World: Realities and Challenges. Springer.

Barton, A. J., Armstrong, G., Preheim, G., Gelmon, S. B., \& Andrus, L. C. (2009). A national Delphi to determine developmental progression of quality and safety competencies in nursing education. Nursing outlook, 57(6), 313-322.

Creswell, J. W., \& Creswell, J. D. (2017). Research design: Qualitative, 
quantitative, and mixed methods approaches. Sage publications.

Gunawan, M. A. (2015). Statistik

Penelitian bidang pendidikan, psikologi dan sosial. Yogyakarta:

Parama Publishing.

Harmer, J. (2012). The Practice of English Language Teaching. Cambridge United Kingdom: Longman.

Herrington, A., Hodgson, K., \& Moran, C. (2009). Teaching the New Writing: Technology, Change, and Assessment in the 21st-Century Classroom. Language \& Literacy Series. Teachers College Press. 1234 Amsterdam Avenue, New York, NY 10027.

Hyland, K. (2015). Teaching and researching writing. Routledge.

Limantoro, S. W. (2016). Practical strategies to improve students' writing skill.

Kraft, M. A., \& Gilmour, A. F. (2017). Revisiting the widget effect: Teacher evaluation reforms and the distribution of teacher effectiveness. Educational Researcher, 46(5), 234-249.

Kurtz, S., Draper, J., \& Silverman, J. (2017). Teaching and learning communication skills in medicine. CRC press.

Martins, D. S. (Ed.). (2015). Transnational writing program administration. University Press of Colorado.

Morrow, C. K. (2018). Communicative language testing. The TESOL encyclopedia of English language teaching, 1-7.

Reinders, H., \& Benson, P. (2017). Research agenda: Language learning beyond the classroom. Language Teaching, 50(4), 561-578.

Woodard, W. J. (2016). Teaching Techniques: Audiovisual Feedback in EFL/ESL Writing Classes. In English Teaching Forum (Vol. 54, No. 2, pp. 29-32). US Department of State. Bureau of Educational and Cultural Affairs, Office of English Language Programs, SA-5, 2200 C Street NW 4th Floor, Washington, DC 20037.

Zaim, M., \& Ningsih, K. (2019, August). Coherence and Unity of Students' Writing on Background of the Study of Research Proposal. In 1st International Conference on Education Social Sciences and Humanities (ICESSHum 2019). Atlantis Press.

Zohrabi, M. (2013). Mixed Method Research: Instruments, Validity, Reliability and Reporting Findings. Theory \& practice in language studies, 3(2). 